\title{
PROGNOSTIC SIGNIFICANCE OF OCCULT LYMPH NODE MICROMETASTASIS IN GASTRIC CANCER: A HISTOCHEMICAL AND IMMUNOHISTOCHEMICAL STUDY BASED ON 1997 UICC TNM AND 1998 JGCA CLASSIFICATIONS
}

\author{
Significância prognóstica das micrometástases ocultas em linfonodos no câncer \\ gástrico: estudo histoquímico e imunoistoquímico baseado nas classificações \\ UICC TNM de 1997 e JCGCA de 1998
}

Nelson Fausto DELL'AQUILA Jr. ${ }^{1}$, Fábio Pinatel LOPASSO ${ }^{2}$, Roberto FALZONI ${ }^{3}$, Kiyoshi IRIYA ${ }^{3}$, Joaquim GAMA-RODRIGUES ${ }^{4}$

ABCDDV/618

Dell'Aquila Jr. NF, Lopasso FP, Falzoni R, Iriya K, Gama-Rodrigues J. Prognostic significance of occult lymph node micrometastasis in gastric cancer: a histochemical and immunohistochemical study based on 1997 UICC TNM and 1998 JGCA classifications. ABCD Arq Bras Cir Dig 2008;21(4): 164-9

ABSTRACT - Background - Micrometastasis is a single or a cluster of malignant cells inside the lymph node that are not detected by routine histopathological sections. Micrometastasis is related to poorer prognosis in many gastric cancer studies the real significance of these cells is still controversial. Aim - To evaluate if lymph node micrometastasis is a significant independent prognostic factor and important risk factor for recurrence in gastric cancer. Methods - A total of 1290 lymph nodes from 28 patients with gastric cancer, since 1998 until 2003, treated by radical resection (D2 and modified D3 lymphadenectomies) were studied. Three sections per lymph node were stained by Hematoxilin-Eosin, histochemical (AB-PAS) and immunohistochemical (AE1-AE3) techniques. Kaplan-Meier's survival curves and Log-rank/Cox tests were used in order to compares lymph node micrometastasis positivity, depth (pT) and location of tumor in gastric wall, histologic type, lymphatic, vascular and perineural invasion, lymph node status $(\mathrm{pN})$ and stage. Results - There were worse prognosis and recurrence in patients with positive lymph node micrometastasis related to vascular and perineural invasions, advanced lymph node status and advanced stages. Conclusion - Lymph node micrometastasis seems to be a significant independent prognostic factor and important risk factor for recurrence in gastric cancer, in a context of radical D2 lymphadenectomy

HEADINGS - Stomach neoplasms. Clinical-dynamic prognosis. Classification.

\section{INTRODUCTION}

Prognosis of patients with gastric cancer is influenced by the presence of metastasis 2 $^{2,12,13,24}$, lymph nodal status has been correlated as the most important individual prognostic factor ${ }^{20}$. There wereearly gastric cancer patients, treated radically, who died of recurrence ${ }^{19}$. There also are reports that $\mathrm{D} 2$ lymphadenectomy improves survival even in $\mathrm{pN} 0$ patients ${ }^{19}$. These may be due at least in part to the presence of lymph node micrometastasis at the time of resection. Although it is not consensual, micrometastasis can be defined as one single cell or a cluster of

From the ${ }^{1}$ Hospital Geral Pirajussara-Secretaria deSaúde-Governo do Estado de São Paulo, ${ }^{2}$ Department of Gastroenterology, University of São Paulo School of Medicine, ${ }^{3}$ Department of Pathology, University of São Paulo School of Medicine, ${ }^{4}$ Hospital Alemão Oswaldo Cruz, São Paulo,SP, Brazil.

Correspondence: Joaquim Gama-Rodrigues, e-mail: cbed@cbed.org.br malignant cells inside of the lymph node that are not visualized by routine methods, but only by special dies, as immunohistochemical AE1-AE3 techniqu es $^{1,4,6,11,18,29,33,35,36,38}$. In order to clarify this issue we studied 28 patients prospectively, treated by radical surgery, minimum of 30 lymph nodes resected from D2 lymphadenectomy and 43 lymph nodes from modified D3 lymphadenectomy.

\section{METHODS}

One hundred eighteen patients were treated by surgery at Department of Gastroenterology, at the University of São Paulo School of Medicine, São Paulo, Brazil, from February 1998 to October 2000. The inclusion criteria were: 1 . endoscopic confirmed biopsy of gastric adenocarcinoma, without previous treatment; 2. no previous malignancies or abdomi- 
nal surgery or neoadjuvant treatment; 3 . no distant metastasis detected by X-ray, ultrasound, CT-scan or visible, palpable or frozen sections biopsies confirmed from liver, peritoneum or lymph nodes classified as M (JGCA 1998) (or M1 LYM) (UICC TNM 1997) or even other location different from esophagus, duodenum, greater or lesser omentum; 4. no severe systemic illness. The main objectives in this coort of patients are select patients with endoscopic and biopsy proved diagnose of gastric cancer, to be submitted to total or subtotal radical gastrectomy D2 lymphadenectomy (JGCA 1998), staged previously or during surgery free of peritoneal, liver and distant lymph node metastasis. We prospectively correlate the histochemical and immunohistochemical (AB-PAS/AE1-AE3) detection of lymph node micrometastasis with clinical and pathological features as: age, gender, tumor size, depth and location of the tumor in the gastric wall, type of lymphadenectomy, type of gastrectomy, histologic type of tumor, lymphatic, vascular and perineural invasion, lymph nodal status, stage studied by (1997 UICC TNM) and 1998 JGCA classifications and follow-up survival curves.

Data of 28 patients who underwent potentially curative resection for gastric cancer from February 1998 to October 2000 were admitted to study by fulfilling the inclusion criteria. These patients were closely followed until November 2003; the median length of follow-up was 25 months. Routine follow-up consisted of physical examination, laboratory test (including CEA, CA19.9 levels), endoscopy, chest radiography, abdominal and pelvic ultrasonografy and abdomen (CT) computed tomography or diagnostic videolaparoscopy in case of suspicion of recurrence. Follow-up intervals vary from one, to six months depending on the stage and months of follow-up or as needed.

Radical gastrectomy and lymphadenectomy were performed in all cases.

However immunohistochemical analysis was performed exclusively in negative H\&E staining technique concerning metastatic invasion. Lymph nodes were studied based in three sections by H\&E, AB-PAS and AE1-AE3 techniques. Mucines were treated by $1 \%$ periodic acid, schiff reagent and alcian blue in $\mathrm{pH} 2.5$ and the malignant cells were detected in purple. Antibodies against human cytokeratins AE1-AE3 (Dako Corporation, Carpinteria, CA 93013 USA) were used in order to identify the cytokeratins of malignant cells inside lymph nodes (peroxidaseantiperoxidase technique). Endogenous peroxidasis was blocked. Dark brown insolvable precipitate was formed peripherically around malignant cells (Figure 1).

\section{Statistical analysis}

Lymph nodes micrometastasis positivity and clinicopathological factors were compared, with special reference to prognosis and survival curves. Statistically significant differences were analyzed with the

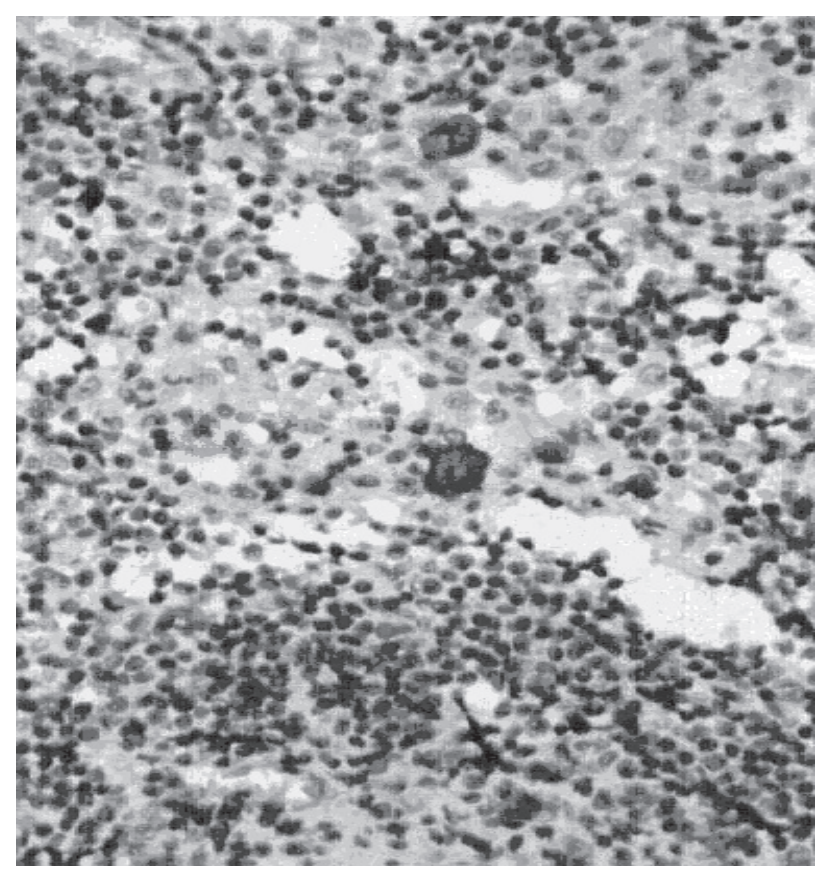

FIGURE 1 - Lymph node micrometastases detected by immunohistochemistry (AE1/AE3 x400)

two-tailed $\chi^{2}$ test, Student's t test or Mann-Whitney test. Kaplan-Meier's survival curves and Log-rank/ Cox tests were used. The risk factors were determined by means of logistic regression analysis. Forward stepwise selection with a likeness ratio test was used for selecting variables. The odds ratio in logistic regression analysis was defined as the ratio of the probability that an event will occur to the probability that it will not occur. The prognostic power of variables was expressed by calculation of a relative risk or odds ratio with $95 \%$ confident interval. $P<0.05$ was considered statistically significant. All statistical analyses were carried out with the SPSS 12.0 for Windows program (SPSS, Chicago, Illinois, USA).

\section{RESULTS}

The mean age of the patients was 61.6 years (range, 35-77 years), with peak incidence in the sixth decade. The total number of resected lymph nodes was 1290 , the average of D2 lymphadenectomy was 37.2, median 33 (30-50), the average of modified D3 (D2+ $\alpha$ ) was 62.1, median 61.5 (43-86) (Table 1).

The overall average of resected lymph nodes was 46.1, median 46 (30-86). According to 1998 JGCA(2nd edition) stage classification 11 stained by H\&E $17.9 \%$ of patients were stage IA, $14.3 \%$ were stage IB, $10.7 \%$ were stage II, $21.4 \%$ were stage IIIA, $28.6 \%$ were stage IIIB and $7.1 \%$ were stage IV. According to 1997 UICC TNM (5th edition) 37 stage classification stained by H\&E $17.9 \%$ of patients were stage IA, $14.3 \%$ were stage IB, $10.7 \%$ were stage II, $32.1 \%$ were stage IIIA, $10.7 \%$ were stage IIIB and $14.3 \%$ were stage IV (Table 2). 
TABLE 1 - Clinical and pathological characteristics of gastric cancer patients with and without lymph node $(\mathrm{Ln})$ micrometastasis, univariate analysis results

\begin{tabular}{|c|c|c|c|c|c|}
\hline \multirow{2}{*}{$\begin{array}{l}\text { Variable } \\
\text { Staining }\end{array}$} & \multicolumn{2}{|c|}{$\begin{array}{l}\text { Positive Ln } \\
\text { micrometastasis }\end{array}$} & \multicolumn{2}{|c|}{$\begin{array}{l}\text { Negative Ln } \\
\text { micrometastasis }\end{array}$} & \multirow[t]{2}{*}{$P$ Value } \\
\hline & AB-PAS & AE1-AE3 & AB-PAS & AE1-AE3 & \\
\hline Age (years) & $59.3 \pm 12.6$ & $61.0 \pm 12.6$ & $63.4 \pm 10.5$ & $62.2 \pm 10.6$ & ns \\
\hline \multicolumn{6}{|l|}{ Gender } \\
\hline Male (18) & 8 & 10 & 10 & 8 & \\
\hline Female (10) & 5 & 5 & 5 & 5 & $\mathrm{~ns}$ \\
\hline $\begin{array}{l}\text { Tumor size } \\
(\max \text { diameter in } \mathrm{cm})\end{array}$ & $6.2 \pm 3.2$ & $5.8 \pm 3.2$ & $4.7 \pm 3.0$ & $4.5 \pm 2.9$ & $\mathrm{~ns}$ \\
\hline \multicolumn{6}{|l|}{$\mathrm{pT}$ (depth of invasion) } \\
\hline pT1 (5) & 1 & 2 & 4 & 3 & \\
\hline pT2 (7) & 2 & 2 & 5 & 5 & \\
\hline pT3 (15) & 10 & 11 & 5 & 4 & \\
\hline pT4 (1) & 0 & 0 & 1 & 1 & \\
\hline Total (28) & 13 & 15 & 15 & 13 & ns \\
\hline \multicolumn{6}{|c|}{$\begin{array}{l}\text { Location of tumor in } \\
\text { stomach }\end{array}$} \\
\hline Upper (4) & 2 & 2 & 2 & 2 & \\
\hline Middle (6) & 4 & 5 & 2 & 1 & \\
\hline Lower (14) & 4 & 5 & 10 & 9 & \\
\hline Whole (4) & 3 & 3 & 1 & 1 & $\mathrm{~ns}$ \\
\hline \multicolumn{6}{|l|}{ Lymphadenectomy } \\
\hline D2 (18) & 7 & 9 & 11 & 9 & \\
\hline D3 (10) & 6 & 6 & 4 & 4 & ns \\
\hline \multicolumn{6}{|l|}{ Type of Gastrectomy } \\
\hline Total (15) & 9 & 10 & 6 & 5 & \\
\hline Subtotal (13) & 4 & 4 & 9 & 9 & ns \\
\hline \multicolumn{6}{|l|}{ Histological type } \\
\hline Differentiated(7) & 5 & 4 & 2 & 3 & \\
\hline Undifferentiated (21) & 11 & 11 & 10 & 10 & ns \\
\hline \multicolumn{6}{|l|}{ Lymphatic invasion } \\
\hline Positive (10) & 7 & 8 & 3 & 2 & \\
\hline Negative (18) & 6 & 7 & 12 & 11 & ns \\
\hline \multicolumn{6}{|l|}{ Vascular invasion } \\
\hline Positive (4) & 4 & 4 & 0 & 0 & \\
\hline Negative (24) & 9 & 11 & 15 & 13 & $P<0.05$ \\
\hline \multicolumn{6}{|l|}{ Perineural invasion } \\
\hline Positive (14) & 10 & 11 & 4 & 3 & \\
\hline Negative (14) & 4 & 3 & 11 & 10 & $P<0.01$ \\
\hline \multicolumn{6}{|c|}{$\begin{array}{l}\mathrm{pN} \text { (lymph node inva- } \\
\text { sion/JGCA) }\end{array}$} \\
\hline pN0 $(8 / 7)^{*}$ & 0 & 0 & 8 & 7 & \\
\hline pN1 (7) & 3 & 3 & 4 & 4 & \\
\hline pN2 $(9 / 8)^{*}$ & 7 & 6 & 2 & 2 & \\
\hline $\mathrm{pN} 3(4 / 6)^{*}$ & 3 & 6 & 1 & 0 & \\
\hline Total (28) & 13 & 15 & 15 & 13 & $P<0.01$ \\
\hline \multicolumn{6}{|l|}{$\begin{array}{l}\mathrm{pN} \text { (lymph node inva- } \\
\text { sion/UICC) }\end{array}$} \\
\hline pN0 $(8 / 7)^{*}$ & 0 & 0 & 8 & 7 & \\
\hline pN1 (10/9)* & 5 & 4 & 5 & 5 & \\
\hline $\mathrm{pN} 2(4 / 6)^{*}$ & 3 & 6 & 1 & 0 & \\
\hline pN3 (6) & 5 & 5 & 1 & 1 & \\
\hline Total (28) & 13 & 15 & 15 & 13 & $P<0.01$ \\
\hline \multicolumn{6}{|l|}{ Stage (JGCA) } \\
\hline IA (4/3) & 0 & $0^{\mathrm{a}}$ & 4 & $3^{\mathrm{a}}$ & \\
\hline IB (5) & 1 & $1^{\mathrm{a}}$ & 4 & $4^{\mathrm{a}}$ & \\
\hline II (1) & 0 & $0^{\mathrm{a}}$ & 1 & $1^{\mathrm{a}}$ & \\
\hline IIIA (6/5) & 4 & $3^{\mathrm{a}}$ & 2 & $2^{\mathrm{a}}$ & \\
\hline IIIB (8) & 5 & $5^{\mathrm{a}}$ & 3 & $3^{\mathrm{a}}$ & \\
\hline IV (4/6) & 3 & $6^{\mathrm{a}}$ & 1 & $0^{\mathrm{a}}$ & \\
\hline Total (28) & 13 & 15 & 15 & 13 & $P<0.05^{\mathrm{a}}$ \\
\hline
\end{tabular}

* - $\mathrm{pN}$ variable changes according to staining techniques (AB-PAS/AE1-AE3) a - Stage is related to statistical difference $(P<0.05)$ between positive and negative Ln micrometastasis only in AE1/AE3 staining ns - not significant
From 1290 lymph nodes retrieved of 28 patients, 152 (11.8\%) lymph nodes were positively detected by hematoxilin-eosin staining (H\&E) and 1138 (88.21\%) were negative. After H\&E technique all 1228 remaining lymph nodes were sectioned three times again and $197(16 \%)$ lymph nodes were positive for AB-PAS histochemical staining. After AB-PAS technique, AE1-AE3 was performed and 1216 lymph nodes were studied by three sections and 225 (18.5\%) lymph nodes were positive for AE1-AE3 technique. There were 4.8\% and $5.7 \%$ losses in lymph nodes number, respectively in histochemical and immunohistochemical techniques, mostly by technical staining/sectioning problems and small size of lymph nodes. From 28 patients studied, there were 13 patients $(46.4 \%)$ who had at least one positive lymph node for micrometastasis stained by histochemical technique among H\&E negative lymph nodes.

TABLE 2 - Stage and upstage based on H\&E, AB-PAS and AE1-AE3 staining and 1998JGCA/1997 UICC TNM classifications

\begin{tabular}{|c|c|c|c|c|c|c|c|}
\hline & CLASSIFICATION & JGCA & UICC & JGCA & UICC & JGCA & UICC \\
\hline & STA & $\mathrm{H}$ & $\mathrm{H} \& \mathrm{E}$ & As & S & $\begin{array}{l}\text { AE1- } \\
\text { AE3 }\end{array}$ & $\begin{array}{l}\text { AE1- } \\
\text { AE3 } \\
\end{array}$ \\
\hline \multirow{6}{*}{ 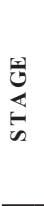 } & IA & $5(17,9 \%)$ & $5(17,9 \%)$ & $4(14,3 \%)$ & $4(14,3 \%)$ & $3(10,7 \%)$ & $3(10,7 \%)$ \\
\hline & IB & $4(14,3 \%)$ & $4(14,3 \%)$ & $5(17,9 \%)$ & $5(17,9 \%)$ & $5(17,9 \%)$ & $6(21,4 \%)$ \\
\hline & II & $3(10,7 \%)$ & $3(10,7 \%)$ & $1(3,6 \%)$ & $1(3,6 \%)$ & $1(3,6 \%)$ & $1(3,6 \%)$ \\
\hline & IIIA & $6(21,4 \%)$ & $9(32,1 \%)$ & $6(21,4 \%)$ & $8(28,6 \%)$ & $5(17,9 \%)$ & $6(21,4 \%)$ \\
\hline & IIIB & $8(28,6 \%)$ & $3(10,7 \%)$ & $8(28,6 \%)$ & $3(10,7 \%)$ & $8(28,6 \%)$ & $5(17,9 \%)$ \\
\hline & IV & $2(7,1 \%)$ & $4(14,3 \%)$ & $4(14,3 \%)$ & $7(25 \%)$ & $6(21,4 \%)$ & $7(25 \%)$ \\
\hline
\end{tabular}

Numbers in bold show stage changing

From same 28 patients studied, there were 15 patients (53.6\%) who had been stained positive, for micrometastasis at this time by immunohistochemical technique among $\mathrm{H} \& \mathrm{E}$ negative lymph nodes cases.

The final stage, after detection of lymph node micrometastasis by special techniques: AB-PAS and AE1-AE3 that was not identified in routine staining H\&E were upstaged (Table 2).

The overall survival average rate was $47.1 \%$, limited to 69 months. Regarding to AE1-AE3 technique, for 15 patients with detected lymph node micrometastasis the survival average rate was $21.5 \%$ (28.2 months, limited to 63 months) For 13 patients with not detected lymph node micrometastasis the survival average rate was $69.2 \%$ (51.6 months, limited to 69 months). At the time of the final follow up 11 patients (39.3\%) were still alive, 3 $(10.7 \%)$ were lost to follow-up and $14(50 \%)$ died from recurrence. Occult lymph node micrometastasis in routine H\&E detected by immunohistochemical technique (AE1-AE3) had worse prognosis (Log-rank/Cox tests $\mathrm{p}<0.05)$. The presence of lymph node micrometastasis had prognostic significance in patients with gastric cancer in this coort (Figure 2).

Vascular and perineural invasions, lymph nodal status, stage and survival were correlated to positive lymph node micrometastasis. The survival curves were performed and patients with lymph node micrometastasis had poorer prognosis (Figure 2). 


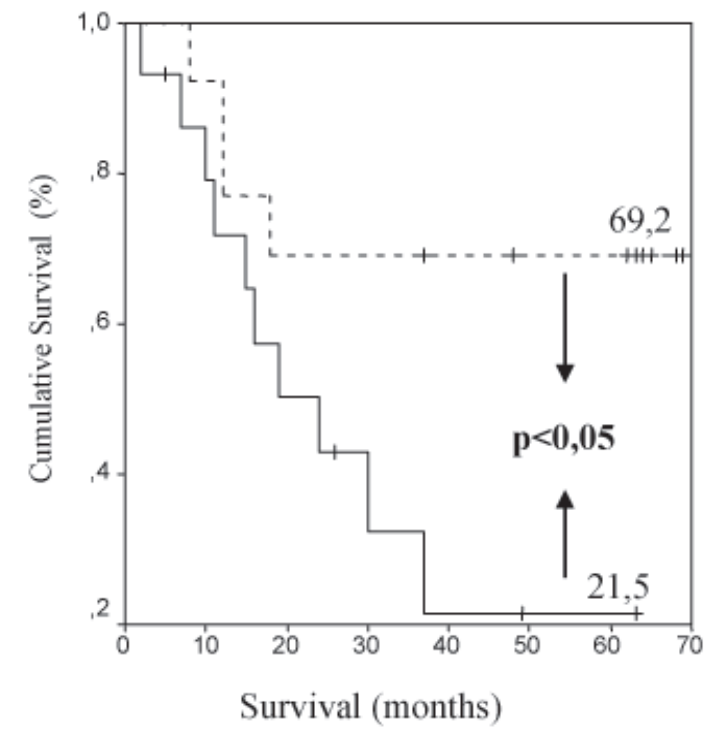

FIGURE 2 - Survival curve for gastric cancer patients with lymph node micrometastasis (continuous line) was lower compared with those without lymph node (interrupted line) detected micrometastasis $(P<0.05)(\mathrm{Cox})$

\section{DISCUSSION}

It is well established that depth of tumor invasion in gastric wall (pT), lymph node invasion $(\mathrm{pN})$ and distant/ peritoneal metastasis (pM) are important prognostic factors in gastric cancer ${ }^{2,12,13,24}$. Lymph nodal invasion can be detected from $36 \%$ to $54 \%$ of all cases of gastric cancer $^{19,20,33,38}$. Prognosis is related to lymph nodal status ${ }^{19}$. "Residual tumors" and remnant positive lymph nodes left behind can lead to "recurrence" in gastric cancer. Recurrence can occur even in early gastric cancer treated with radical resections, as reported in 1996, by Maehara et al. ${ }^{19}$, 34 patients died of recurrence, part of them due to lymph node micrometastasis.

Micrometastasis can be defined by a single malignant cell or a cluster of malignant cells inside lymph node not detected by routine techniques as H\&E, but only detected by special techniques as histochemical and immunohistochemical staining ${ }^{1,46,6,11,18,29,31,33,35,36,37,38}$. There are others definitions for micrometastasis as malignant cells cluster smaller than $2 \mathrm{~mm}$ in diameter ${ }^{32}$, smaller than $0.5 \mathrm{~mm}^{27}$ and 5 or less cells ${ }^{15}$, all of them with stromal reaction such as granulation or desmoplastic tissue. In the other hand microinvolvement can be described as individual tumor cells without stromal reaction ${ }^{32}$.

There are authors that do not agree that might be a statistical difference in prognostic significance of patients with and without lymph node micrometastasis $3,5,14,22,23,30,34$. Stachura et al..$^{34}$, in 1998, after had studied retrospectively 40 patients with early gastric cancers for the presence of micrometastasis in regional lymph nodes by cytokeratin 18 immunostaining related that micrometastasis had no effect on patients survival and takes more than the diagnosis of micrometastasis alone to estimate its real prognostic significance in theirs series. Fukawaga et al. ${ }^{5}$, in 2001, reported a rate of $35.5 \%$ micrometastasis among 107 patients classified as pT2pN0M0 (JGCA 1998) detected by immunohistochemical AE1-AE3 staining, treated by D2, there was difference between infiltrative and expansive tumors $(P=0.02)$ related to detected micrometastasis, greater in the first one, but not in survival or prognosis between patients with and without detected micrometastasis. Morgagni et al. in $2001^{22}$ and $2003^{23}$ reported large number of patients with early gastric cancer, treated radically, that were not influenced by micrometastasis presence at all, in other words, there was no difference in survival or prognosis for such early gastric cancer patients.

Reversely, there are several authors that agree that there is significant difference in prognostic and survival among patients with and without lymph node micrometastasis $8,9,10,17,19,26,28,39$.

Ishida et al. ${ }^{9}$, in 1997, reported 2446 lymph nodes removed from 109 gastric cancer patients stained with hematoxilin-eosin, Alcian blue in combination with periodic acid-Schiff stain and antibodies against cytokeratin and carcinoembryonic antigen (CEA). Metastases were confirmed in 230 lymph nodes $(9.4 \%)$ stained with H\&E, an additional 201 lymph nodes (17.6\%) had micrometastasis identified only by immunostaining for cytokeratin (197 lymph nodes) and/or CEA. Adenocarcinomas with micrometastasis had significantly worse prognoses at Stage II. Between the two histologic types of gastric carcinoma established by Lauren16, the diffuse type had more micrometastasis than the intestinal type. The presence of micrometastasis in lymph nodes is an indispensable factor in determining the prognosis of gastric carcinoma patients. Cai et al. ${ }^{2}$, in 2000, examined 1945 lymph nodes of 79 patients with submucosal gastric cancer by two consecutive sections for H\&E and immunostaining with anticytokeratin antibody (CAM 5.2), and demonstrated a lesser 5-year survival in the group of patients with micrometastasis in lymph nodes. Harrison et al. ${ }^{8}$, in 2000, related a retrospective review of 25 patients, from 1981 to 1998 , resected for T1-4N0M0 gastric and gastroesophageal junction adenocarcinoma who underwent immunohistochemical analysis with CAM 5.2, the median number of lymph nodes resected was 7(1-33), the median follow-up time was 25 months (range 4-195) with an overall survival rate of $55 \%$. For patients with evidence of lymph node micrometastasis $(\mathrm{n}=9)$, the 5 -year survival rate was significantly decreased (35\%), compared to a $66 \% 5$-year survival rate for negative patients $(\mathrm{n}=16$, $P=0.05$ ). The presence of immunohistochemical detected lymph node micrometastasis correlates with worse prognosis for patients with histologic negative gastric cancer lymph nodes and immunohistochemical techniques may be a useful additional staging modality in this subset of patients. Ishigami et al. ${ }^{10}$, in 2003 reported 4203 lymph nodes examined retrospectively, from 180 gastric cancer patients and not detected any micrometastasis in submucosal gastric cancer patient who underwent lymph node dissection. Gastric cancer patients with more than six 
metastatic lymph nodes all had nodal micrometastasis. Patients who were detected positive for micrometastasis had a significant poorer survival rate than those without micrometastasis $(P<0.05)$

Because most of studies were done retrospectively and patients submitted to several adjuvant treatments, it is possible that there is still a role for a rigid quality-controlled lymphadenectomy and prospective study to elucidate this issue. Even after curative resections, recurrence can occur in patients with early gastric cancer ${ }^{16}$. Gotoda et al. ${ }^{7}$ studied more than 5,000 early gastric cancer patients who had undergone gastrectomy with lymph node dissection at the National Cancer Center Hospital and the Cancer Institute Hospital in Tokyo and none of the 1230 well differentiated intramucosal of less than $30 \mathrm{~mm}$ diameter regardless of ulceration findings were associated to metastases nor the 929 early lesions without ulceration regardless tumor size. None of the 145 differentiated adenocarcinomas of less than 30-mm-diameter without lymphatic or venous permeation were associated with metastases. Based in risk factors and field evidence by large number of patients a gastric cancer guideline in Japan was built ${ }^{25}$.

Lymphatic system has an important role in spread of gastric cancer metastasis, as well as of lymph node micro- metastasis, mainly in undifferentiated histological types, restricted to blue nodes and lymph nodes within the dye flow area of patent blue used in sentinel node navigation surgery for early gastric cancers ${ }^{21}$.

Apart from the clinical and pathologic prognostic factors in gastric cancer, others molecular biological studies have suggested new prognostic factors that are now being extensively investigated: growth factors and receptors (epithelial growth factor, transforming growth factor $\mathrm{T}-\beta 1$ receptor); oncogenes and suppressor genes (c-erb B2, ras, HST-1, K-sam, c-met, p53, DCC, Rb P21 and nm23); cell adhesion molecules (integrins, cadherin, immunoglobulin superfamily, CD44); chromosome deletion of 1q, 5q, 7p, 17p; tissue inhibitor of metalloproteinasis and urokinasis plasminogen activator and microsatellite instability among others.

\section{CONCLUSION}

Lymph node micrometastasis seems to be a significant independent prognostic factor and important risk factor for recurrence in gastric cancer, in a context of radical lymphadenectomy. Immunohistochemical AEI-AE3 techniques may disclose occult lymphnode micrometastasis and so contribute to refine pathological staging in gastric cancer.

Dell'Aquila Jr. NF, Lopasso FP, Falzoni R, Iriya K, Gama-Rodrigues J. Significância prognóstica das micrometástases ocultas em linfonodos no câncer gástrico: estudo histoquímico e imunoistoquímico baseado nas classificações UICC TNM de 1997 e JCGCA de 1998. ABCD Arq Bras Cir Dig 2008;21(4):164-9

RESUMO - Racional - Micrometástases são um conjunto de células malignas dentro de linfonodo que não são detectadas pelos exames histopatológicos de rotina. Elas são relacionadas a prognóstico mais pobre em muitos estudos sobre câncer gástrico, mas a real significância dessas células permanece controversa. Objetivo - Avaliar se micrometástase linfonodal é um fator independente de prognóstico e importante para detectar a recurrência do câncer gástrico. Métodos - Um total de 1290 lifonodos de 28 pacientes com câncer gástrico, de 1998 a 2003, tratados com operações radicais (D2 e D3 modificadas) foram revistos. Três secções por linfonodo foram corados por Hematoxilina-Eosina, histoquímica (AB-PAS) e imunoistoquímica (AE1-AE3). Curvas de sobrevida de Kaplan-Meyer e teste de Log-rank/Cox foram usados para comparar positividade das imcrometástases, profundidade (pT) e localização tumoral na parede gástrica, tipo histológico, invasão linfática, vascular e perineural, estado linfonodal (pN) e estádio onde se encontra a doença. Resultados - Houve pior prognóstico e recurrência nos pacientes com linfonodos com micrometástases relacionadas às invasões vascular e perineural, avançado estado de invasão linfática e estadiamento mais elevado. Conclusão - Micrometástase parece ser importante e independente fator de risco para recurrência no câncer gástrico no contexto das linfadenectomias radicais D2.

DESCRITORES - Câncer gástrico. Prognóstico Clínico Dinâmico. Classificação.

\section{REFERENCES}

1. Bryne J, Waldron R, McAvinchey D, Dervan P. The use of monoclonal antibodies for the histopathological detection of mammary axilary micrometastasis. Eur J Surg Oncol 1987;13:409-11.

2. Cai J, Ikeguchi M, Maeta M, Kaibara N. Micrometastasis in lymph nodes and microinvasion of the muscularis propria in primary lesions of submucosal gastric cancer. Surgery 2000;127:32-9.

3. Choi HJ, Kim YK, Hong SH. Occurence and prognostic implications of micrometastasis in lymph nodes from patients with submucosal gastric carcinoma. Ann Surg Oncol 2002;9(1):13-9.

4. Davidson B, Sams R, Styles J, Deane C, Boulos PB. Detection of occult nodal metastasis in patients with colorectal carcinoma. Cancer 1990;65:67-70.

5. Fukagawa T, Sassako M, Mann G. Immunohistochemically detected micrometastasis of lymph nodes in patients with gastric carcinoma. Cancer 2001;92:4753-61.

6. Galea MH, Athanassiou E, Bell J, Dilks B, Robertson JFR, Elston CW. Occult regional lymph node metastasis from breast carcinoma: immunohistological detection with antibodies CAM 5.2 and NCRC-11. J Pathol 1991;165:221-7.

7. Gotoda T, Yanagizawa A, Sasako M, Ono H, Nakanishi Y, Shimoda T. Incidence of lymph node metastasis from early gastric cancer: estimation with a large number of cases at two large centers. Gastric Cancer 2000,3:219-25.
8. Harrison L E, Choe J K, Goldstein M, Meridian A. Prognostic significance of immunohistochemical micrometastasis in node negative gastric cancer patients. J Surg Oncol 2000;73:153-57.

9. Ishida K, Katsuyama T, Sugiyama A, Kawasaki S.Immunohistochemical evaluation of lymph node micrometastasis from gastric carcinomas. Cancer 1997; 79:1069-76

10. Ishigami S, Natsugoe S, Tokuda K, Nakajo A. Clinical impact of micrometastasis of the lymph node in gastric cancer. The American Surgeon 2003;69:573-7.

11. JGCA-1998-Japanese Gastric Cancer Association-Japanese Classification of Gastric Carcinoma-2 ${ }^{\text {nd }}$ English Edition. Gastric Cancer 1998;1:10-24.

12. Katai H, Maruyama K, Sassako M, Sano T, Okajima K, Kinoshita T. Mode of recurrence after gastric cancer surgery. Digest Surg 1994;11:99-103.

13. Kikuchi Y, Tsuchiya A, Ando Y, Yoshida T, Takenosita S. Immunohistochemical detection of lymph node microenvolvement in node-negative gastric cancer. Gastric Cancer 1999;2:173-8.

14. Kim S, Choi Y, Hong S. Occurence and prognostic implications of lymph node micrometastasis in patients with submucosal gastric cancer. In: Annals of the 4th international gastric cancer congress, New York; Monduzi Editore 2001;391-5. 
15. Komukai S, Nishimaki T, Watanabe H, Ajioka Y, Suzuki T, Hatakeyama K. Significance of immunohistochemically demonstrated micrometastases to lymph nodes in esophageal cancer with histologically negative nodes. Surgery 2000;127:40-6.

16. Lauren P. The two histological main types of gastric carcinoma: diffuse and so-called intestinal type carcinoma. An attempt at histoclinical classification. Acta Path Microbiol Scandinav 1965;64:31-49.

17. Lee E, Chae Y, Kim I, Choi J. Prognostic relevance of immunohistochemically detected lymph node micrometastasis in patients with gastric carcinoma. Cancer 2002;94(11):2867-73.

18. Maehara Y, Baba H, Ohno S, Sugimachi K. Cytokeratin staining reveals micrometastasis in lymph node of early gastric cancer [letter]. Surgery 1995; 117:480.

19. Maehara Y, Oshiro T, Endo K, Baba H, Oda S, Ichiyoshi Y, Kohnoe S, Sugimachi K. Clinical significance of occult micrometasatasis in lymph nodes from patients with early gastric cancer who died of reccurence. Surgery 1996;119:397-402.

20. Maruyama K, Gunven P, Okabayashi K, Sassako M, Kinoshita T. Lymph node metastases of gastric cancer. General pattern in 1931 patients. Ann Surg. 1989;210:596-602.

21. Miyake K, Seshimo A, Kameoka S. Assessment of lymph node micrometastasis in early gastric cancer in relation to sentinel nodes. Gastric Cancer 2006;9:197202.

22. Morgagni P, Saragoni L, Folli S, Gaudio M, Scarpi E, Bazzochio F, Marra GA, Vio A. Lymph node micrometastasis in patients with early gastric cancer: experience with 139 patients. Annals of Surgical Oncology 2001;8(2):170-4.

23. Morgagni P, Saragoni L, Scarpi E, Zattini PS. Lymph node micrometastasis in early gastric cancer and their impact on prognosis World J Surg 2003;27,558561.

24. Moriguchi S, Maehara Y, Korenaga D. Risk factors which predict pattern of recurrence after curative surgery for patients with advanced gastric cancer. Surg Oncol 1992;1:341-6.

25. Nakajima T. Gastric cancer guidelines in Japan. Gastric Cancer 2002;5:1-5.

26. Nakajo A, Natsugoe S, Ishigami S, Matsumoto M, Nakashima S, Hokita S, Baba M, Takao S, Takashi A. Detection and prediction of micrometastasis in the lymph nodes of patients with pN0 gastric cancer. Ann Surg Oncol $2001 ; 8(2) 158-162$.

27. Natsugoe S, Aiko T, Shimazu H. A detailed histological study on occult metastasis of the lymph nodes. Jpn J Surg 1991;21:528-32.
28. Natsugoe S, Nakashima S, Matsumoto S, Matsumoto M, Nakajo A, Miyazono F, Kijima F, Ishigami S. Paraaortic lymph node metastasis and tumor cell microinvolvement in advanced gastric cancer. Gastric Cancer 1999;2:179-85.

29. Sedmak DD, Meineke TA, Knehtges DS. Detection of metastatic breast carcinoma with monoclonal antibodies to cytokeratin. Arch Pathol Lab Med 1989; 113:786-9.

30. Shin SH, Cho SY, Bae JH, Koo YU et al. Significance of lymph node micrometastasis in advanced gastric cancer In: Annals of the 4th international gastric cancer congress, New York; Monduzi Editore 2001;325-8.

31. Siewert J R, Böttcher K, Roder JD, Busch R, Hermanek P, Meyer HJ and the German Gastric Carcinoma Study Group. Prognostic relevance of systematic lymph node dissection in gastric carcinoma. Br J Surgery 1993;80:1015-8.

32. Siewert JR, Kestlmeier R, Busch R, Böttcher K, Roder JD, Müller J, Fellbaum $\mathrm{C}$, Höfler $\mathrm{H}$. Benefits of D2 lymph node dissection for patients with gastric cancer and pN0 and pN1 lymph node metastases. Br J Surgery 1996;83:1144-7.

33. Sloane JP, Ormerod MG, Imire S, Coombs RC. The use of antisera to epithelial membrane antigen in detecting micrometastasis in histological sections. Br J Cancer 1980;42:392-8.

34. Stachura J, Zembala M, Heitzman J, Korabiowska M, Schauer A. Lymph node micrometastasis in early gastric carcinoma alone inadequately reflect the new model of metastatic development. Pol J Pathol 1998;49:155-7.

35. Stosiek P, Kasper M, Karsten U, Goertchen R. Detection of cancer metastasis in regional lymph nodes: comparative histological and immunohistological investigations with the broad-range anticytokeratin monoclonal antibodie A45-B/B3. Neoplasm 1991;38(1):43-7.

36. Trojani M, De Mascarel I, Bonichon F, Coindre JM, Delsol G. Micrometastasis to axilary lymph nodes from carcinoma of the breast: detection by immunochemistry and prognostic significance. Br J Cancer 1987;55:303-6.

37. UICC TNM 1997-Sobin LH, Wittekind CH, editors:TNM Classification of Malignant Tumors (5th ed.). International Union Against Cancer (UICC). New York, Wiley-Liss, 1997;59-62.

38. Well CA, Heryet A, Brochiedr J, Gatter KC, Mason DY. The immunocytochemical detection of axilary micrometastasis in breast cancer. Br J Cancer 1984;50:193-7.

39. Yasuda K, Adachi Y, Shiraishi A. Prognostic effect of lymph node micrometastasis in patients with histologically node-negative gastric cancer. Ann Surg Oncol 2002;9(8):771-4.
Fonte de financiamento: não há Conflito de interesse: não há Recebido para publicação: 30/05/2008 Aceito para publicação: 15/08/2008 